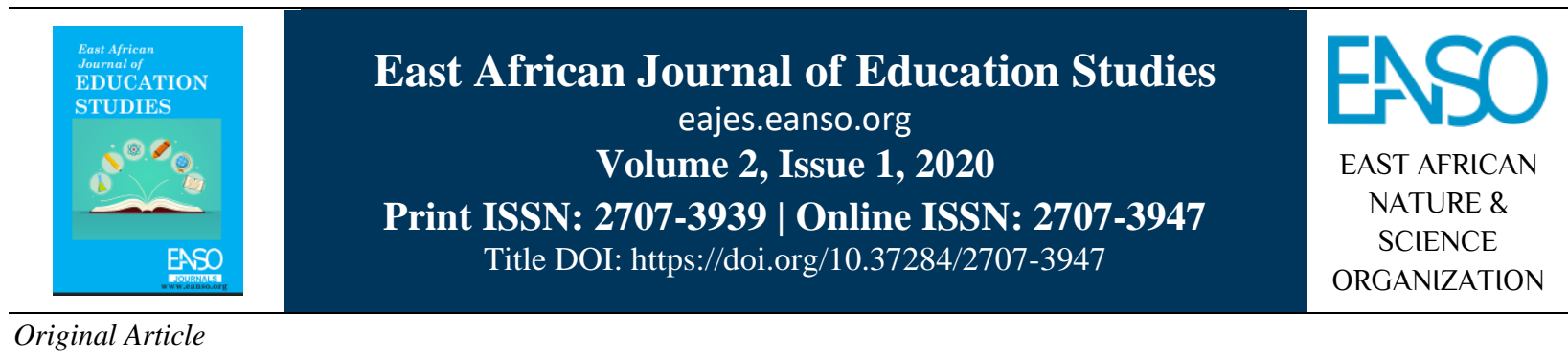

\title{
Setting the Basis for Success in the Competency-Based Curriculum: Experiential Instruction Process Issues in Emergent Reading in Kenya
}

\author{
Dr. Philomena Chepsiror ${ }^{1 *}$ \\ ${ }^{1}$ Moi University. P. O. Box 3900, Eldoret, Kenya. \\ *Correspondence email: chepsirorpj@gmail.com \\ ORCID: https://orcid.org/0000-0001-9280-1478
}

Article DOI: https://doi.org/10.37284/eajes.2.1.162

\section{Date Published: ABSTRACT}

11 June 2020 Study after study has shown that reading is the single most important skill necessary for success in school and life. Emergent reading is the first stage in

Keywords: the developmental continuum in learning to read and consists of the skills,

Emergent Reading, Instructional Process

Issues,

Experiential Learning, Competency-Based

Curriculum. knowledge, and attitudes that are presumed to be developmental precursors to conventional reading. In other words, students who are unable to grasp early print concepts as emergent readers may experience difficulty with reading later. In this regard, multiple assessments of reading have reported poor reading achievement in Kenyan primary school children. The Uwezo studies since 2010, for instance, have highlighted a reading crisis. The reports indicate that there has been no improvement in reading from the inception of the study despite the government launching intervention programs among them 'Tayari' and 'Tusome' which were meant to improve reading skills. This study investigated the instructional process issues in emergent reading in a bid to unravel this predicament. The study was carried out in Bureti SubCounty in Kericho County. It involved a sample of 95 pre-primary 1 teachers randomly selected from public and private schools. Data was collected using an observation checklist, a questionnaire a focused group discussion and was analysed descriptively. Instructional process factors found to impede experiential emergent reading strategies included unclear goals for reading lessons, pressure from parents for quicker learning outcomes, time allocated for the experiences was insufficient, that the teachers were overloaded with other responsibilities, large pupil numbers, among others. The results of the study will inform evidence-based policy on the implementation of the Competency-based Curriculum in Kenya and any other part of the world. 


\section{APA CITATION}

Chepsiror, P. (2020). Setting the Basis for Success in the Competency-Based Curriculum: Experiential Instruction Process Issues in Emergent Reading in Kenya. East African Journal of Education Studies, 2(1), 25-37. https://doi.org/10.37284/eajes.2.1.162.

\section{CHICAGO CITATION}

Chepsiror, Philomena. 2020. "Setting the Basis for Success in the Competency-Based Curriculum: Experiential Instruction Process Issues in Emergent Reading in Kenya". East African Journal of Education Studies 2 (1), 25-37. https://doi.org/10.37284/eajes.2.1.162.

\section{HARVARD CITATION}

Chepsiror, P. (2020) "Setting the Basis for Success in the Competency-Based Curriculum: Experiential Instruction Process Issues in Emergent Reading in Kenya”, East African Journal of Education Studies, 2(1), pp. 25-37. doi: 10.37284/eajes.2.1.162.

\section{IEEE CITATION}

P. Chepsiror, "Setting the Basis for Success in the Competency-Based Curriculum: Experiential Instruction Process Issues in Emergent Reading in Kenya”, EAJES, vol. 2, no. 1, pp. 25-37, Jun. 2020.

\section{MLA CITATION}

Chepsiror, Philomena. "Setting the Basis for Success in the Competency-Based Curriculum: Experiential Instruction Process Issues in Emergent Reading in Kenya". East African Journal of Education Studies, Vol. 2, no. 1, Jun. 2020, pp. 25-37, doi:10.37284/eajes.2.1.162.

\section{INTRODUCTION}

An extensive body of research makes it clear that reading is at the heart of every child's success. Therefore, school outcomes and good performance in different subjects depending on children's ability to read. Since more advanced skills acquired in later grades depend on early years of schooling, children who do not acquire these reading skills in their early grades struggle to acquire more advanced skills usually absorbed through reading. Thus, teaching children how to read during the early years is critical in promoting learning to read. Learning to read is a sequential process; each new skill builds on the mastery of previously learned skills. This study endeavoured to find out whether the alarming literacy crisis in Kenya is related to the acquisition of emergent literacy skills.

Studies have also shown that there is a direct relationship between the number of senses engaged in learning and the amount and quality of retention achieved over time. Good learning experiences are ones that are actively engaging and enable children to use many of their senses, such as touch, sight, hearing, smell, and taste (Darkenwald \& Merriam, 1982; Wigfield et al., 1997). Therefore, success in achieving reading proficiency in children centres on experiences emanating from children's enjoyment of reading, motivation to read and confidence in their aptitude. Caregivers and pre-school teachers should encourage children's learning by providing varied and interesting things for children to do and they should interact with them to help them make sense of these experiences.

\section{Statement of the Problem}

Emergent literacy has become a central feature of schooling as it often predicts later success of a student. However, Uwezo assessments across Kenya, Tanzania and Uganda have highlighted the reading crisis since 2010 . The key observation has been that budgets and other inputs to learning have been increasing steadily, but learning outcomes have remained essentially stagnant (Uwezo, 2015; 2016). Uwezo has established that high deficits of reading exist at all levels, close to ten per cent of learners exiting the primary schools in Kenya (standard eight) lack the basic competencies of literacy and numeracy of grade two-level (Uwezo, 2012; 2017). The 2016 report reveals that a significant proportion of children in Grade 3 cannot read a single word drawn out of class two work.

Since the Government of Kenya has increased allocation in the past decade three-fold in the primary school sector through Free Primary Education (FPE) and capitation grants for Early Childhood Development and Education (ECDE), the lack of resources is unlikely to be the core problem behind these poor results. The 2012 Uwezo report shows that Kenyan public schools have trained teachers in abundance. Therefore, the issue of teacher qualification is out of the question. The idea of teachers handling large numbers in 
class may be a contributing factor, but the problem is persistent even in counties that have low enrolments (Uwezo, 2012). This, therefore, shows that there are other underlying causes to this problem. Arguably, improving the foundational skills of literacy has the prospective to improve learning in the whole schooling channel and even affect learning for a lifetime. It is against this backdrop that this study of Bureti Sub-County set out to investigate instructional process issues hindering experiential learning in emergent reading. This becomes a perfect justification for experiential learning in the Competency-Based Curriculum that is being implemented in Kenya.

\section{LITERATURE REVIEW}

In 1996, Kagan coined the phrase "a pleasing idea." Which became the foundation of "emergent literacy?" (Whitehurst \& Lonigan, 1998). The term means the skills, knowledge, and attitudes that are presumed to be developmental precursors to conventional forms of reading and writing. Emergent reading is derived from this term and it means the point at which a person transits from being a non-reader to a reader. It denotes the idea that the acquisition of literacy is best conceptualized as a developmental continuum with its origins early in the life of a child. These skills have been identified as strong predictors of later student outcomes and in closing the achievement gap. Strickland and Riley-Ayers (2006) affirm that effective classroom instruction in ECDE is the key to creating strong, competent readers and to preventing reading difficulty, or simply, emergent reading is a leading indicator.

Foley et al. (2008) define leading indicators as those that provide early signals of progress toward academic achievement. According to Musen (2010), early reading proficiency is used as a leading indicator because there is a greater perspective for learning reading skills in the early grades. He says that right through K-12 school experience children continue to build upon prior knowledge to develop grade-level academic skills and knowledge. Reading progress changes most considerably in the early years and slower in the later years. Musen believes that by third grade, students are expected to know the basics of reading and be able to apply reading skills across the curriculum. This shift from "learning to read" to "reading to learn" is difficult for children who have not mastered basic reading skills. As they get older, struggling readers find themselves with less and less access to texts that are getting more and more intricate.

Emergent reading is generally described as the behaviours of reading that lead to conventional reading and "comprises all of the actions, understandings and misunderstandings of learners engaged in experiences that involve print creation or use" (Koppenhaver \& Erickson, 20037, and these experiences are not only necessary but closely related to later literacy outcomes (Justice \& Kaderavek, 2004). Emergent literacy behaviours and understandings are therefore directly related to opportunity and experience. Justice and Kaderavek among others have proposed oral language, phonological awareness, concept development, knowledge of the conventions of print and print intentionality, alphabetic knowledge and rich literacy environments as components that facilitate emergent literacy.

Oral language is the foundation of literacy development. A child's oral vocabulary development is one of the most visible and important aspects of language acquisition in children (Richgels 2004). The number of words in a child's vocabulary is an indicator of his or her linguistic health and a factor in his or her ability to use language in varied contexts and for multiple purposes. Strickland and Riley-Ayers (2006) confirm that Oral language activities provide children with a sense of words and sentences and builds sensitivity to sound system so that children can acquire phonological awareness and phonics. Through their speech, children demonstrate their understanding of the meanings of words and written materials. Oral language development is facilitated when children have many opportunities to use language in interactions with adults and each other and when they listen and respond to stories. Young children build vocabulary when they engage in activities that are cognitively and linguistically stimulating and encouraging them to describe events and build background knowledge.

Environmental print too has a stake of influence on children's literacy. Marrs (2019) avers that 
environmental print is an effective way to help children understand the concept that combinations of letters have meaning. It helps build alphabet knowledge as children begin to recognize letters in a variety of different signs, words, and contexts. The signs, logos, and words children see every day around them in their environments that are used for real-life functions daily to achieve individual needs and goals have the potential to foster young children's development of emergent literacy skills (Neuman \& Roskos, 1990; Teale \& Sulzby, 1987).

Skills on the alphabetical code are also predictive of future reading abilities. Knowledge of the alphabet letters and phonological awareness (the ability to distinguish the sounds within words form the basis of early decoding and spelling ability) are both correlated with later learning. Young children can learn to name letters and to distinguish them from each other.

Phonological awareness is the ability to analyse and dissect the sound structures within language (Schuele \& Boudreau, 2008). Schuele and Boudreau suggest that pre-kindergartners and early kindergarteners need to focus on lower levels of phonological awareness skills, such as rhyming, alliteration, and syllables. By the middle of kindergarten, it is anticipated that most students will have mastered these skills and be ready for the later part of kindergarten.

To help children develop emergent reading skills various developmentally appropriate strategies and interventions that promote functional outcomes have been made. This includes establishing predictable routines to encourage children to learn to anticipate events. Wheater (2011) believes that when routines are established, children begin to learn about objects and vocabulary associated with certain activities. Active participation in all steps of a routine can reinforce concepts and language skills. Routines can also help a child to develop sequencing skills (first/then; start/finish), and some tasks can be arranged in left to right order, such as setting the table, laying out clothes, or arranging materials for any activity.

Children should be exposed to reading within the daily routine. Lavigne (2005) insists that the child should be included in the course of reading and writing lists, directions, recipes, menus, messages or letters to friends and family, and any other activities that occur within routine activities. Adults need to be creative in finding ways to make reading activities that children may not be able to observe accessible to the child. A case in point is to ask the child to help you think of the things you might need to buy when you go to the grocery by checking what is out of stock in the kitchen store or the refrigerator. When you get back home, it is prudent to refer back to the list with the child to be sure that you got everything on it.

Another strategy is to provide concrete languageembedded experiences. Texas School for the Blind and Visually Impaired advocates for children to be allowed to experience things through hands-on activities that are meaningful and fun. Since through incidental learning children lack access to information, they often will need precise instruction (Lavigne, 2005). For example, storytelling about animals will only be meaningful, if children have first had the chance to visit a zoo, seen different types of animals, touched their fir or feathers, listened to their calls (roar, growl, laugh), examined what they eat and observed how they walk.

It is important to create a communication-rich environment with meaningful activities in the natural context. Children should be provided with a variety of experiences to support children's communication and language skills. Chandler et al. (2008) believe that the development of a wide range of vocabulary and concepts are essential to success in literacy. Caregivers and teachers need to model appropriate language throughout the day. Adults need to engage in conversations with children, give descriptions of objects, activities, events or objects that interest them. For example, during snack time, the teacher can ask children questions about their favourite snacks, what they like to eat at home or engage them in conversations about colours, textures or tastes of different snacks.

Morrow (2002) believes that to promote children's early literacy and beginning to read, teachers should place an emphasis on providing literacy-rich environments that promote social interaction, peer collaboration, and learning experiences in both explicit and problem-solving situations. Learning should be related to real-life experiences that are meaningful and functional. Ample time and space 
should be provided for children to learn through play, manipulation, and exploration. In essence, children should have an abundance of first-hand experiences on which generalized notions can be built. Therefore, classrooms must provide different experiential strategies to meet an individual learner's areas of strength to be the most successful.

\section{Read Aloud}

Allen (2009) emphasizes the importance of reading aloud to children. This allows them to enjoy special individual attention, to strengthen language and concept development, and to build up skills of handling a book. Allen outlined basic steps to follow when reading a book with a young child to make the experience more pleasant, meaningful and fun for both the adult and the child. These steps include choosing a book that relates to the child's own experiences, reading at a pace that is appropriate to the child and providing props to supplement the illustrations. Concrete objects, movements, and sounds may all help make experiences more pleasant, meaningful and fun. The teacher also needs to modify the book to meet the child's individual needs and interests, add texture, colour, tactile cues, or anything to enhance the experience. It is also imperative to make the book more accessible to the child.

Play is indispensable when dealing with young children. Hatton and Sapp (2005) designate play as vital to the normal development of a child. A child learns more through play than by any other means, since at play the child learns because they are personally involved in what is worthwhile to them. Therefore, the knowledge the child acquires is more valuable because they gain it from their own experience. Each activity brings about some change in the child's idea, feelings, or actions. Therefore, play is crucial in the imparting of emergent literacy skills. Ford (2010) believes that children must have a direct encounter with what they are learning and take individual liability for their learning. Learning by doing allows children to become personally invested in their learning process. Becoming actively engaged in their learning builds confidence, as lessons require learners to rely on their abilities to obtain knowledge. Lessons for reading in the formative stages should, therefore, be play-based heavily relying on hands-on experiences. Play-based activities comprise physical activity such as block building, reading games, Graphic Arts, visual expression, critical looking and picture reading; verbal expression, for example, dramatic and role-play, and other firsthand related activities.

\section{Book and Print Awareness}

National Research Council (2001) indicated that a child's sensitivity to print is a major first step toward reading. With awareness of print young children can begin to understand that print is everywhere in the world around them, and that reading and writing are ways for them to get ideas, information, and knowledge. Children quickly settle into book-sharing routines with primary caregivers. Children begin to recognize favourite books by their cover, pretend to read books and understand that books are handled in certain ways. As they reach their fourth and fifth years, children increasingly come to understand that it is the print that is read in stories and that this print contains alphabet letters that are a special category of visual items. They begin to recognize that print in English has several features, such as starting at the top of the page (top to bottom) and on the left side of the page (left to right). They recognize print in their home, neighbourhood, and other local environments. Efforts to engage children in early literacy activities cultivate that emerging awareness. The Theoretical framework

This study was guided by the Experiential learning theory by Kolb (1984). According to Kolb learning is the process whereby knowledge is created through the transformation of experience. Kolb asserts that effective learning is seen when a person progresses through a cycle of four stages; of having a concrete experience followed by observation of and reflection on that experience which leads to the formation of abstract concepts (analysis) and generalizations (conclusions) which are then used to test the hypothesis in future situations, resulting in new experiences. These stages are presented in Figure 1. 
Figure 1: Kolb's stages of experiential learning

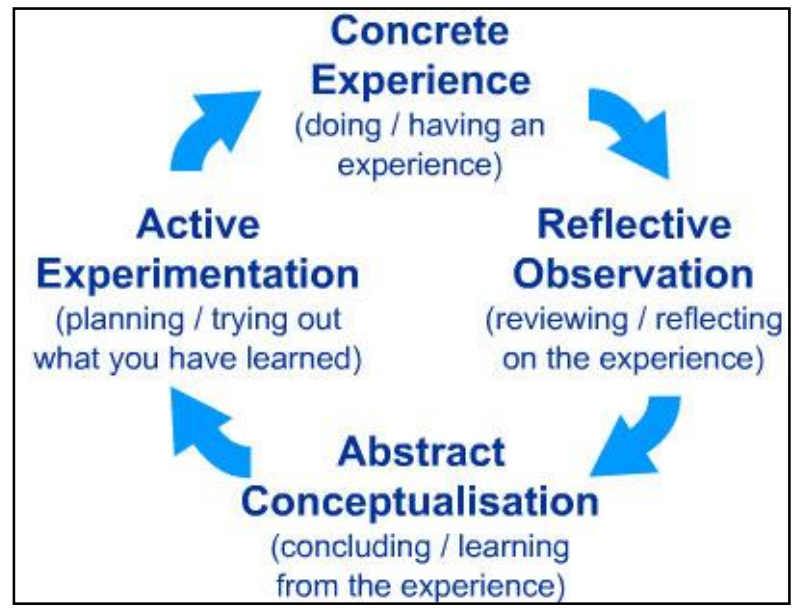

Source: (Mcleord, 2013)

\section{Concrete Experiences}

Concrete experiences imply that the learner encounters a new experience in the leaning process. The learner is not a passive receptacle but an active participant and there is physical movement, not just sitting. This is based on the philosophy that learners learn best through active engagement in meaningful activities. In the classroom situation, therefore, the teacher should begin by guiding the learners through concrete and personalized experiences. When a child learns through concrete experiences, the learning becomes internalized and remains part of his being. To stimulate children's engagement in the activities, the teacher should provide plenty of opportunities that require observation, inquiry and problem solving, all of which lead to a high level of thinking and interest in the activity within an environment that has interesting materials and equipment.

\section{Reflexive Observation}

For learning to occur reflection on action must take place. Reflection consists of those processes in which learners engage to recapture, notice and reevaluate their experiences, to work with their experience, to turn it into learning (Boud \& Walker, 1992). Leaners need to think about an event that has occurred or the activity they have just carried out to assimilate the meaning of the activity. There is a need for students to process the information; they need to relate it to their previous knowledge, and they need to test their understanding of what took place and to relate it to their everyday experiences. Reflection should be incorporated throughout the activity. At the beginning of the activity, the learner needs to consider what will occur. During the experience, the learner needs to deal with the feelings that occur as a result of the experience. The teacher should not just assume that the learner understands the material; rather he/she should seek feedback from learners. The learners respond in a way the teacher gets to confirm that the learner has interpreted the message and made sense of the activity correctly. The teacher should also set aside time after the experience to think about and record what has occurred. He/she should solicit the learner's meaning of the activity. This can be done by allowing learners to compare notes in groups, having roundtable discussions, carrying out a post mortem of the activity or individually thinking quietly about the events, or making sense of experiences he/she has had, and then allow them to review or reflect by collecting data on that experience.

\section{Abstract Conceptualization}

The learners then analyse and interpret the data and use it to make their conclusions from what they have observed and more often than not relate it to real-life situations. From the data and observations, the learners develop new skills that help them draw some lessons from their experiences and learn from them. This, in turn, makes them adjust their attitudes and adopt new ways of thinking. Reflection gives rise to a new idea or a modification of an existing abstract concept. Guided practice takes effect at this stage. The teacher should clearly and accurately show the learners how to perform an activity, the teacher demonstrates a new skill as the pupils watch. The teacher works with learners to practice the new skill as he/she gauges who understands the concepts and processes and to further remodel or re-teach the skill if necessary.

\section{Active Experimentation}

Learners need to test new ideas discussed in the classroom in real-life situations. Trying out a practice presents a lush opportunity for reflection even if the trials fail. The teacher now accords the learners plenty of opportunities to practice the new 
skill. As learners look for new ways to do things, they are likely to find that the search itself will reenergize their learning and finally modify their behaviour through the new knowledge and by choice of new experiences. For purposes of teaching early reading, strategies including block building, graphic arts, sand and water play, housekeeping and music and movement and other forms of experiential engagements should be introduced to help children's phonological awareness, alphabetical knowledge and vocabulary building. To acquire maximum learning, children need to be able to practice these skills in a spontaneous way rather than the teacher structuring their play. Children are very imaginative and when left to work on their own they are apt to come up with their new ideas and ways of doing things which are equally as useful for learning.

All four stages of the cycle must be negotiated by the learner. This way, ideas are formed and reformed through experience. Kolb's learning stages could be used by teachers to critically evaluate the learning condition typically available to learners, to develop more appropriate learning opportunities and put their learners at a definite learning edge. Throughout the experiential learning process, everything from increased creativity to authentic problem-solving opportunities occurs.

Experiential learning is a crucial learning strategy in the twenty-first century. From it, learners gain Transferrable skill sets that every learner needs to achieve to flourish in today's complex world. Conrade and Haden (1995) were concerned about administering experiential learning programs for the total development of young learners. According to them, the development is seen jeopardized by a social milieu that increasingly isolates young learners from the kind of experiences, encounters and challenges that form the basis for healthy development. Kolb's experiential learning theory was very useful in constructing the study tools for assessing these challenges.

\section{METHODOLOGY}

This study was conducted in selected schools in Bureti Sub-County, in Kericho County South Rift region of Kenya. It used the survey research design. Krejcie and Morgan's (1970) recommended sample size schedule was used to select 95 Pre-Primary 1 (PP1) school teachers proportionately drawn from 61 public and 34 private Pre-primary school centres. The reason for choosing pre-primary 1 teacher was because it is at this level that emergent reading experiences from home environments are picked and developed. To obtain the data for the study, observation, checklist, interview schedule and the questionnaire were used. During the first phase of the study, the researcher and research assistants observed two pre-primary 1 teachers in each of the five zones in Bureti Sub-County selected randomly from the study sample. The observation checklist was used to check on the amount of experiential learning used for a single observed lesson. The amount of lesson time was rated as " 1 : Most of the time, 2: half of the time, 3 : a little time and 4: not used at all". The results were used as a guide for the second phase of the study. In the second phase of the study, questionnaires were administered to the 95 selected respondents. The data was analysed descriptively.

\section{Data analysis and discussion}

The observation checklist was used to assess the approximate amount of time spent on experiential activities in a reading lesson. The results are presented in Table 1.

Table 1: Class observation on the time spent on experiential learning in a reading lesson

\begin{tabular}{lll}
\hline $\begin{array}{l}\text { Time Spent in Reading Lessons } \\
(\mathbf{n = 1 0})\end{array}$ & F & \% \\
\hline Most of the time & 0 & 0 \\
Half of the time & 2 & 20 \\
A little time & 6 & 60 \\
Not used at all & 2 & 20 \\
\hline
\end{tabular}

The result of the observation revealed that majority of the observed lessons, 6(60\%) practised experiential learning just for a little while, whereas $2(20 \%)$ had experiential activities half of the time, while $2(20 \%)$ did not have an experiential activity at all. This was the basis for the construction of the questionnaire and interview schedule for the next phase of the study.

This study then embarked on establishing teacher's opinions about instructional process aspects that hampered their choice of experiential strategies for 
East African Journal of Education Studies, Volume 2, Issue 1, 2020

Article DOI: https://doi.org/10.37284/eajes.2.1.162

teaching reading. Nine items were presented to the selected PP1 teachers. The results are presented in Table 2.

Table 2: Instructional process factors hampering teachers using experiential strategies in teaching reading

\begin{tabular}{|c|c|c|c|c|c|c|c|c|c|c|c|c|}
\hline \multirow[b]{3}{*}{ Instructional aspects } & \multicolumn{6}{|c|}{ Public } & \multicolumn{6}{|c|}{ Private } \\
\hline & \multicolumn{2}{|l|}{$\mathbf{A}$} & \multicolumn{2}{|l|}{$\mathbf{U}$} & \multicolumn{2}{|l|}{ DA } & \multicolumn{2}{|l|}{$\mathbf{A}$} & \multicolumn{2}{|l|}{$\mathbf{U}$} & \multicolumn{2}{|c|}{ DA } \\
\hline & $\mathbf{F}$ & $\%$ & $\mathbf{F}$ & $\%$ & $\mathbf{F}$ & $\%$ & $\mathbf{F}$ & $\%$ & $\mathbf{F}$ & $\%$ & $\mathbf{F}$ & $\%$ \\
\hline Goals for the reading lessons not clear & 38 & 62.30 & 2 & 3.28 & 21 & 34.43 & 21 & 61.76 & 0 & 0 & 13 & 38.24 \\
\hline $\begin{array}{l}\text { Feedback to the pupils not immediate i.no } \\
\text { mark or grade assigned to the activity }\end{array}$ & 42 & 68.85 & 1 & 1.64 & 18 & 29.51 & 29 & 85.29 & 1 & 2.94 & 4 & 11.76 \\
\hline Time assigned for a lesson not adequate & 50 & 83.33 & 0 & 0 & 11 & 18.03 & 30 & 88.24 & 0 & 0 & 4 & 11.76 \\
\hline $\begin{array}{l}\text { Teachers responsibilities in other classes } \\
\text { (overloaded) }\end{array}$ & 47 & 77.05 & 2 & 3.29 & 12 & 19.67 & 18 & 52.94 & 0 & 0 & 16 & 47.06 \\
\hline $\begin{array}{l}\text { Pupils do not see the significance of the } \\
\text { activities }\end{array}$ & 29 & 47.54 & 5 & 8.20 & 27 & 44.26 & 23 & 67.65 & 0 & 0 & 11 & 32.35 \\
\hline $\begin{array}{l}\text { Pressure from parents for quicker learning } \\
\text { out comes }\end{array}$ & 39 & 63.93 & 0 & 0 & 22 & 36.06 & 32 & 94.18 & 0 & 0 & 2 & 5.88 \\
\hline $\begin{array}{l}\text { The large number of pupils in the class } \\
\text { compels the teacher to go for teacher } \\
\text { centre strategies }\end{array}$ & 52 & 85.25 & 0 & 0 & 9 & 14.75 & 20 & 58.82 & 0 & 0 & 14 & 41.18 \\
\hline $\begin{array}{l}\text { Teachers can't think of enough suitable } \\
\text { activities for every lesson }\end{array}$ & 30 & 49.18 & 6 & 9.84 & 25 & 40.98 & 24 & 70.59 & 2 & 5.89 & 8 & 23.53 \\
\hline $\begin{array}{l}\text { The space available is not sufficient for } \\
\text { carrying out activities }\end{array}$ & 18 & 29.51 & 2 & 3.28 & 41 & 67.21 & 22 & 64.71 & 1 & 2.94 & 11 & 32.35 \\
\hline
\end{tabular}

Key: $A=$ agree, $U=$ Neutral, DA: Disagree

The first item sought to find out if the clarity of instructional goals affected experiential learning strategies for emergent reading as argued by Dean et al. (2012) that

"The key to making your students' learning experiences worthwhile is to focus planning on major instructional goals, phrased in terms of desired student outcomes-the knowledge, skills, attitudes, values, and dispositions that you want to develop in your students."

The results in Table 2 indicate that majority of the teachers, 38(62.30\%) in public ECDE centres believed the fact that experiential learning was hampered by the goals for their reading lessons not being clear. A similar belief emerged in private ECDE centres where $21(61.76 \%)$ accepted that unclear goals hindered their choice of experiential learning strategy. It turns out that many teachers do not think seriously about the lesson goals when planning for reading lessons. This is what one interviewed participant confessed,

"So long as I plan my teaching procedure well and make my lesson interesting, I don't think putting down a goal will make a difference in my teaching."

This goes against what scholars like Kelly (2018) who recognize that stated goals and objectives, 
provide a measure of whether a particular lesson plan produces the desired learning results.

The second item sought to find out whether feedback on the reading lesson affected the use of experiential learning for teachers in Bureti subcounty. Feedback was looked at in terms of assigning a mark or grade to the activity. The results on Table 2 show that majority of the teachers felt their feedback was not immediate as $42(68.85 \%$ ) in public schools and as 29(85.29\%) in private schools confirmed the statement. However, teachers in private compared with the public had more problems giving feedback. As seen in the classes observed, this could be attributed to a large number of pupils witnessed more in the private than in public schools. Studies related to feedback underscore the importance of providing feedback that is instructive, timely, referenced to the actual task, and focused on what is correct and what to do next (Hattie \& Timperley, 2007; Shute, 2008). They believe that by involving them in the feedback process, teachers can create a classroom environment that fosters and supports learning. They further emphasize that the goal of providing feedback is to give students information about their performance relative to a particular learning objective so they can improve their performance and understand themselves better as learners.

The study endeavoured to find out how teachers regarded time apportioned for an experiential lesson. An overwhelming majority in both public $50(83.33 \%)$ and private $30(88.24 \%)$ were of the strong opinion that time allocated for reading lessons was not adequate. Cryer, Harms \& Riley, (2003) thought that at least 60 minutes being dedicated to children's experiential activities to allow children to engage in lengthy play ideas and help them reach learning goals. This then calls for policymakers to consider allowing more time for experiential activities in the pre-school classroom just like it does in primary and secondary school.

A greater part of respondents $47(77.05 \%)$ in public and $18(52.94 \%)$ in private ECDE centres believed that teachers' responsibilities in other classes hindered the use of activity methods in teaching reading. This could be attributed to the teacher shortages in Kenya as often indicated by stakeholders. In 2019 the Kenya Teachers Service
Commission (TSC) indicated that there was a shortage of 95,258 secondary school teachers and 30,357 primary school teachers (Waihenya \& Nyamai, 2019). This possibly has a ripple effect on staffing in the pre-primary school.

Similarly, 29(47.54\%) respondents in public and $23(67.65 \%)$ acknowledged that when the pupils do not see the significance of the activities, the reading lesson might not be effective. From these figures, it is clear that getting the pupils to see the significance of activities was a problem more in private schools than in private ones. Scholars refer to this as 'establishing a purpose for the lesson'. An established purpose alerts learner to important information and garners their attention while helping teachers decide how best to use their instructional time (Fisher \& Frey, 2011). A lesson objective is in the mind of the teacher; establishing purpose refers to the act of carefully communicating the objective to students. Therefore, an effective teacher must let pupils understand the intent of what they will be doing and what they should be learning. They should see the significance of the activities prepared for a reading lesson which is lacking in this case.

A very substantial quota 32(94.18\%) of respondents in private schools recognized that pressure from parents for quicker learning outcomes is responsible for the failure by teachers to select activity methods in teaching reading while $39(63.93 \%)$ of those in public school acknowledged the same. Parents of this age in time want to see their children read soon after they are enrolled in school. One informer in one of the observed lessons had this to say:

"They term classroom activities as 'mere play'. They label a class laden with activities as a waste of time. They want to see their children able to read and write."

This is contrary to Hirsh-Pasek et al. (2009) who talk about trying to resuscitate playtime's reputation among parents and policymakers who often view play as a waste of valuable learning time and believe that playtime at home and in schools stems from the fear of the risk of falling behind.

The item that stated that a large number of the pupils in the class compelled the teachers to opt for 
teacher-centred methods, therefore avoiding the use of activity methods in teaching reading had $52(85 \%)$ and $20(58.82 \%)$ in public and private respectively in support. This was evident in the ten observed classrooms where the smallest number of pupils was 57 while the largest was 78. In the 2016 Basic Education Statistical Booklet the national teacher/Pupil ratio for ECDE was 1: 29 while for Bureti it was 1: 25; just as recommended by The National Pre-Primary Education Policy Standard Guidelines for a Teacher-Pupil ratio of 1:25 (Republic of Kenya, 2018). This notwithstanding, in the 10 observed classes in Bureti enrolments per class far outweighed the recommended numbers.

It is instructive to note that a majority of respondents, 36(59.02\%) in public schools and $24(70.59 \%)$ in private schools acknowledged that their use of experiential strategies for teaching reading was affected because teachers can't think of enough suitable activities for every lesson. Experiential lessons require the teacher to be very creative in crafting lessons that will keep learners active and retain their interest in every lesson in a unique manner, keeping in mind Burnage's (2018) idea that teachers have to keep exploring ideas and keeping options open. Learners must look forward to every lesson in equal measure. If learners aren't absorbed by what's going on in the lesson, they'll find something else that interests them. Therefore, pre-school teachers have to be very creative in planning for their lessons. However, for these teachers, it can be hard to make time for innovative ideas for their learners and embrace their creativity while trying to juggle curriculum requirements, meeting with parents, testing, dealing with pupil safety matters and other issues in the classroom, given the shortage of teachers and a large number of pupils in classes.

Lastly, the study required respondents to state whether they attributed their limited use of experiential learning to space available. A majority of $41(67.21 \%)$ of the public schools did not seem deterred by the size of space available. However, the contrary was true of the private schools where a majority, 22(64.71\%) stated that space available in their classrooms was not sufficient for carrying out activities. An illustration of one such private school classroom is given in Figure 2, where 68 PP1 learners in a private school were squeezed in a $4 \times 4$ metre classroom. The small benches they sat on carried more than six pupils, the aisles in between were too narrow. The classroom space was far from ideal. The Kenya National Pre-Primary education Policy Standard Guidelines (MOE 2018) stipulates that the standard size of a Pre-Primary classroom shall measure 8x6 meters and accommodate a maximum of 25 children. The teacher in Figure 2 had good experiential learning ideas but could only demonstrate or use one or two pupils to display a concept.

\section{Figure 2: A small crowded classroom}

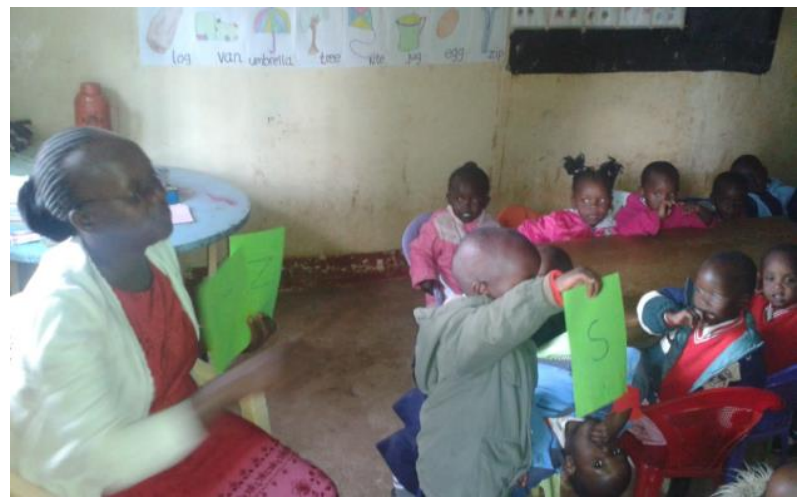

A radar chart was used to compare the strength of each of the nine variables to find out which of them constrained the use of experiential learning most. Radar charts (also known as spider chart) is a graphical method of displaying multivariate data in the form of a two-dimensional chart of three or more quantitative variables represented on axes starting from the same point. The distance from the centre indicates the value of the score in that category. A point close to the centre on any axis indicates a low value. A point near the edge is a high value. Means were used as the measure to compare the values. 
Figure 3: Instructional process factors hampering experiential activities for emergent reading
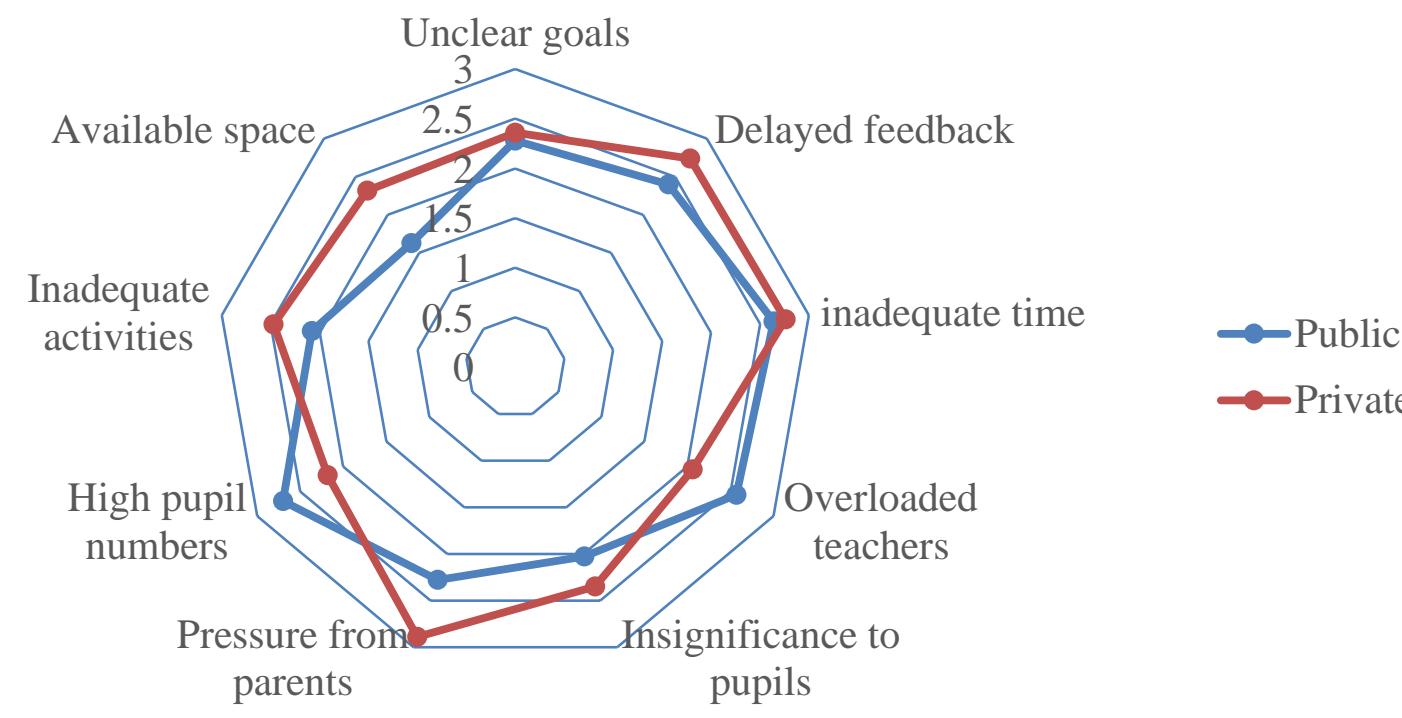

-Private

As seen in figure 3 the aspect that hinders the choice of experiential learning most is pressure from private school parents requiring quicker learning outcomes. This is followed very closely by high pupil numbers in the public school. The lowest was the inadequacy of space available in public schools for carrying out activities (meaning there was enough space in public schools). The point of greatest convergence was the fact teachers are discouraged from using activities when goals for the reading lessons are not clear, followed by the fact that time allocated for ordinary lessons (30 minutes) was not enough for experiential oriented lessons.

\section{CONCLUSION AND RECOMMENDATIONS}

From these results it can be concluded that factors that were directly linked to the teacher were highly to blame whenever the teacher failed to utilize the experiential strategies for teaching reading: Making goals clear to him/her and her pupils, giving timely feedback, being creative when planning for activities scored higher than those many other aspects where the teacher had no control.

Training institutions are required to adjust their training to experiential learning which will remedy most of the anomalies perceived in this study. The
Ministry of Education is also obligated to re-train practising teachers on experiential learning embedded in the new Competency-Based Curriculum. Also, the TSC should employ more teachers as low Teacher/pupil ratio- will ease the teachers' load, giving them enough time to prepare adequate activities appropriate to the level, smaller number of pupils to deal with and to train their energies sufficiently to figure out clear goals for the reading lesson preparation of learning experiences for emergent reading and to give feedback to the pupils at the earliest opportunity possible.

\section{REFERENCES}

Allen, H (2009). Enriching the Reading Experience for Children with Visual Impairments: Reading to Young Children with Vision Loss. Austin, TX: Texas School for the Blind and Visually Impaired: https://www.tsbvi.edu/fall-2011items/3097-enriching-the-reading-experiencefor-children-with-visual-impairments-readingto-young-children-with-vision-loss.

Boud, D., \& Walker, D. (1992). In the midst of experience: Developing a model to aid learners and facilitators. Empowerment through experiential learning, 163-169. 
Burnage, S. (2018). Creative learning, creative teaching. Seced, 2018(11), 10-10.

Chandler, L. K., Young, R. M., Nylander, D., Shields, L., Ash, J., Bauman, B., ... \& Lay, A. (2008). Promoting early literacy skills within daily activities and routines in preschool classrooms. Young Exceptional Children, 11(2), 2-16.

Conrad, D. and Heden, D. (1995). National assessment of experiential education: Summary and implications. In R. J. Kraft and J. Kielsmeier (Eds.), Experiential learning in schools and higher education. (pp. 382403). Dubuque, IA: Kendall/Hunt.

Cryer, D., Harms, T., \& Riley, C. (2003). All about the ECERS-R: A detailed guide in words and pictures to be used with the ECERS-R. Pact House Pub.

Darkenwald, G. G. \& Merriam, S. B. (1982). Adult Education: Foundations of Practice. New York: Harper and Row

Dean, C. B., Hubbell, E. R., Pitler, W. \& Stone, B. J. (2012). Classroom Instruction That Works. Research-Based Strategies for Increasing Student Achievement, $2^{\text {nd }}$ Edition. Alexandria, VA: ASCD.

Fisher, D., \& Frey, N. (2011). The purposeful classroom: How to structure lessons with learning goals in mind. Alexandria, VA: ASCD.

Foley, E., Mishook, J., Thompson, J., Kubiak, M., Supovitz, J., \& Rhude-Faust, M. K. (2008). Beyond Test Scores: Leading Indicators for Education. Annenberg Institute for School Reform at Brown University.

Ford, K. (2010). 8 Strategies of preschool ELLs language and literacy development. Retrieved from Colorin Colorado, available at https://www.colorincolorado.org/article/8strategies-preschool-ells-language-andliteracy-development.

Hattie, J., \& Timperley, H. (2007). The power of feedback. Review of educational research, 77(1), 81-112.
Hatton, D. D. \& Sapp, W. K. (2005). Session 4: What Is Emergent Literacy? In Topor, I., Rosenblum, L. P., \& Hatton, D. D., Visual conditions and functional vision: Early intervention issues (pp. 246-247). Chapel Hill, NC: Early Intervention Training Center for Infants and Toddlers With Visual Impairments, FPG Child Development Institute, UNC-CH.

Hirsh-Pasek, K., Golinkoff, R. M., Berk, L. E., \& Singer, D. (2009). A mandate for playful learning in preschool: Applying the scientific evidence. Oxford University Press.

Justice, L. M. \& Kaderavek, J. N. (2004). Embedded-explicit emergent literacy intervention I: Background and description of the approach. Language, Speech, and Hearing Services in School, 35(3), 201-11.

Kelly, M. (2018). The Everything New Teacher Book: A survival guide for the First Year and Beyond. University of Florida

Kolb, D. A. (1984). Experiential learning: Experience as the source of learning and development. Englewood Cliffs, NJ: PrenticeHall.

Koppenhaver, D. A. \& Erickson, K. A. (2007). Supporting Literacy Learning in All Children. In Giangreco, M. F., \& Doyle, M. B., Quickguides to inclusion: Ideas for educating students with disabilities. Baltimore, MD: Brookes Publishing Company.

Krejcie, R. V. \& Morgan, D. W. (1970). Determining Sample Size for Research Activities. Educational and Psychological Measurement, 30, 607-610.

Lavigne, E. (2005). Essential Literacy Experiences for Visually Impaired Children. Austin TX: Texas School for the Blind and Visually Impaired. Available at http://www.tsbvi.edu/seehear/fall05/essential.h tm.

Marrs, A. (2019, Feb 18). Using Environmental Print to Develop Early Literacy Skills. Retrieved from Cor Advantage, available at 
https://coradvantage.com/blog/environmentalprint/.

McLeod, S. (2010). Kolb's learning styles and experiential learning cycle. Simply psychology.

Morrow, L.M. (2002). The literacy centre: Contexts for reading and writing, 2nd edition. Portland, ME: Stenhouse Publications

Musen, L. (2010). Early reading proficiency: Leading indicators for education. New York, NY: Brown University.

National Research Council. (2001). Chapter 5: Curriculum and Pedagogy: The What and the How of Early Childhood Education. In Bowman, B. T., Donovan, M. S. \& Burns, M. S., Eager to Learn: Educating Our Preschoolers (pp. 82-232). Washington, DC: The National Academies Press.

Neuman, S. B., \& Roskos, K. (1990). Play, print, and purpose: Enriching play environments for literacy development. The reading teacher, 44(3), 214-221.

Republic of Kenya (2018). The National PrePrimary Education Policy Standard Guidelines. Nairobi: Government Printer

Richgels, D. J. (2004). Paying attention to language. Reading research quarterly, 39(4), 470-477.

Schuele, C. M., \& Boudreau, D. (2008). Phonological awareness intervention: Beyond the basics. Language, speech, and hearing services in schools, 39, 3-20.

Shute, V. J. (2008). Focus on formative feedback. Review of educational research, 78(1), 153-189.

Strickland, D., \& Riley-Ayers, S. (2006). Early literacy: Policy and practice in the preschool years. The preschool policy brief, 10, 1-12.

Teale, W. H. \& Sulzby, E. (1987). Literacy acquisition in early childhood: The roles of access and mediation in storybook reading. The future of literacy in a changing world, 1987, 111-130.
Uwezo (2017): Are Our Children Learning? Lessons from Uwezo learning assessments from 2011 to 2015. Dar es Salaam: Twaweza East Africa. Available at https://www.twaweza.org/uploads/files/East $\%$ 20Africa\%20Report\%202015.pdf.

Uwezo. (2012). Are our Children Learning? Annual Learning Assessment Report. Nairobi: Twaweza. Available at http://www.uwezo.net/wpcontent/uploads/2014/05/Kenya-Report-2012WebFinalUpdate.pdf.

Uwezo. (2015). Are our children learning? Literacy and Numeracy across East Africa. Nairobi, KE; Twaweza. Available at https://www.globalreadingnetwork.net/sites/de fault/files/eddata/2013-Annual-Report-FinalWeb-version.pdf.

Uwezo. (2016). Are Our Children Learning? Uwezo Kenya Sixth Learning Assessment Report. Nairobi: Twaweza East Africa

Waihenya, K. \& Nyamai, F. (2019, March 31). Education quality suffers as teacher shortage hits schools. Retrieved from Daily Nation, available at https://www.nation.co.ke/news/education/Edu cation-quality-suffers-as-teacher-shortagehits-schools/2643604-5049350wxy01v/index.html.

Wheater, J. (2011). Strategies to Assist Emergent Literacy Learners in Acquiring Alphabetic Knowledge, Print Awareness, and Phonological Awareness Skills. Master's Thesis. Rochester, NY: St. John Fisher College.

Whitehurst, G. J., \& Lonigan, C. J. (1998). Child development and emergent literacy. Child Development, 69(3), 848-872.

Wigfield, A., Eccles, J. S., Yoon, K. S., Harold, R. D., Arbreton, A. J., Freedman-Doan, C., \& Blumenfeld, P. C. (1997). Change in children's competence beliefs and subjective task values across the elementary school years: A 3-year study. Journal of educational psychology, 89(3), 451. 